Werner Lesslauer ${ }^{\circ}$, Frits Koning, Tom Ottenhoff, Marius Giphart, Els Goulmy and Jon J. van Rood

Department of Immunohaematology and Bloodbank, University Hospital, Leiden

\section{T90/44 (9.3 antigen). A cell surface molecule with a function in human $\mathbf{T}$ cell activation*}

\begin{abstract}
T90/44 is a cell surface antigen which is present on human T cells of the helper and cytotoxic subsets and which binds the 93 monoclonal antibody $\left(93^{\circ} \mathrm{mAb}\right.$ ) It is expressed in the form of $90-\mathrm{kD}$ a disulfıde-bonded dimers of a $44-\mathrm{kD}$ a polypeptide and of free 44-kDa subunits The function of T90/44 was investigated in a series of $\mathrm{T}$ cell function assays $93 \mathrm{mAb}$ was found to mhibit the activation of class II-restricted cloned $\mathrm{T}$ helper cells derived from leprosy patients and reactive with $M$ leprae ant1gens The inhibition was first found at $1-10 \mathrm{ng} / \mathrm{ml} 93 \mathrm{mAb}$ and regularly increased with the antibody concentration The extent of the inhibition varied among different $\mathrm{T}$ cell clones in proportion to the respective different levels of T90/44 expression at their cell surface The proliferative responses of peripheral blood lymphocytes (PBL) to purified protein derivative of $M$ tuberculosis (PPD) and tetanus toxord were enhanced by the $93 \mathrm{mAb}$ resulting in up to $20-30$-fold increase of $\left[{ }^{3} \mathbf{H}\right]$-thymidine incorporation After phytohemagglutının-1nduced activation of $\mathrm{PBL}$, the number of T90/44 molecules per cell expressed at the cell surface rose from day 0 to day 7 by a factor of about 10 High concentrations of $93 \mathrm{mAb}(5-10 \mu \mathrm{g} / \mathrm{ml})$ at low cell densities and in the presence of monocytes in culture media supplemented by fetal calf serum were directly mitogenic for resting lymphocytes The cytolytic eftector functions of class I-restricted cytotoxic T lymphocytes (CTL) were not modulated by $93 \mathrm{mAb}$ The mixed lymphocyte reactions of three class I-restricted CTL to their specific target cells were found not to be significantly influenced by $93 \mathrm{mAb}$ In conclusion it is proposed that an antigen-independent $T$ cell activation pathway can be entered at T90/44
\end{abstract}

\section{Introduction}

The activation of $T$ cells to differentiate and to proliferate are essential steps in the immune response to antigen This tundamental property of the immune system correlates with the $i n$

\section{[I 5625$]$}

\footnotetext{
* This investigation received financial support from the Swiss National Science Foundation (Bern), Roche Research Foundation (Basel), The Foundation for Medical Research FUNGO, The Immunology of Leprosy (IMMLEP) component of the UNDP/ WORLD BANK/WHO Special Programme for Research and Traming in Tropical Diseases, the Netherlands Leprosy Relef Association (NSL) and the Nederlandse Organisatie voor zulverwetenschappelıjk onderzoek (ZWO)

These investigations were carried out during a stay of $\mathrm{W}$ Lesslauer at the Dept of Immunohaematology and Bloodbank of the Univer sity Hospital I eiden
}

Correspondence: Werner Lesslauer, Swiss Institute for Expermental Cancer Research (ISREC), $\mathrm{Ch}$ des Boveresses CH-1066 Epalnges, Switzerland

\begin{abstract}
Abbreviations: APC: Antigen presentung cell(s) CML: Cell-meds ated-Lympholysis CTL: Cytotoxic T cells EBV-BCL: Epstem-Barr virus-transformed B cell lines FACS: Fluorescence dctivated cell sor ter FCS: Inactivated tetal calf serum FITC: Fluorescen sothıcy anate HA-3: Minor histocompdtbblity antigen HA-3 HS: Hedtinactivated human pooled AB serum H-Y: Male specific minor his tocompatibility dntigen IMDM: Iscove's modified Dulbecco's medum mAb: Monoclonal antibody(1es) MHC: Major histocom patibility complex PBL: Perıpherdl blood mononucledr cells PBS: Phosphate buffered salme PHA: Phytohemagglutmin PPD: Purı fred protem derivative of $M$ tuberculosis SDS: Sodium dodecyl sul fate 1T: Tetanus toxord
\end{abstract}

vitro finding that the triggering of the antigen receptor $\mathrm{T}_{1} / \mathrm{T} 3$ antigen complex by appropriately presented antigen or by monoclonal antibodies ( $\mathrm{mAb}$ ) is capable of eliciting prolıferative $T$ cell responses (for review see $[1,2]$ ) The discovery that two mAb directed to epitopes of the T11 antigen in combination also can stimulate $T$ cell growth [3] proved that additional, antigen-independent activation pathways exist More recently, it was found that yet another class of $T$ cell surface molecules, T90/44, in response to the binding of a specific ligand, can drive $T$ cells into proliferation $\mathrm{T} 90 / 44$ binds the $93 \mathrm{mAb}$ [4], it 1 s expressed at the surface of helper $\left(T_{h}\right)$ and cytotoxic $T$ cell subsets in the form of $90-\mathrm{kDa}$ disulfide-bonded dimers of a $44-$ $\mathrm{kDa}$ polypeptide and of free 44-kDa subunits [5-7] The first indication that T90/44 may function in a new antigen-independent $\mathrm{T}$ cell activation pathway was provided by the discovery that $93 \mathrm{mAb}$ strongly enhances prohferative cell responses to phytohemagglutinın (PHA) and allogeneic cells [5] This hypothesis was further supported by the more recent findings that $93 \mathrm{mAb}$ also enhances the mitogenic response to 12-0tetradecanoylphorbol 13-acetate and may act as a direct mitogen $[7,8]$

To assess the functional role of T90/44 in more detal, we have investigated the effects of $93 \mathrm{mAb}$ in cell culture assays with cloned antigen-specific helper cells as well as cytotoxic $T$ cell lines (CTL) and resting normal T cells Our results show that depending on the type of the cells in culture, positive or negdtive signals can be mediated through T90/44, since the activdtion of helper cells by antigen was found to be inhibited by $93 \mathrm{mAb}$, whereds resting $\mathrm{T}$ cells may be activated by $93 \mathrm{mAb}$ An important element in this functional dichotomy may be that T90/44 expression is strongly induced in activated cells The effector function of the CTL could not be influenced by $93 \mathrm{mAb}$, although they were found to express $\mathrm{T} 90 / 44$ 


\section{Materials and methods}

\subsection{Cells}

\subsection{Peripheral blood lymphocytes (PBL) and Epstem-Barr virus-transformed $B$ cell lines (EBV-BCL)}

PBL were isolated from hepannzed venous blood on Ficoll/ Isopaque densty gradients washed $(\times 3)$ In Hanks' balanced salt solution (Gibco, Paisley, Scotland) and resuspended in Iscoves modified Dulbecco's medium (IMDM, Grbco) or RPMI 1640 supplemented with streptomycin $100 \mu \mathrm{g} / \mathrm{ml}$, pencilinn $100 \mathrm{U} / \mathrm{ml}$, both from Flow Laboratories, Irvine Scotland, and $15 \%$ pooled human $\mathrm{AB}$ serum (HS) or $10 \%$ fetal calt serum (FCS) $\mathrm{EBV}-\mathrm{BCL}$ were generated trom $5 \times 10^{\circ}$ autologous PBL according to Steinit $z$ et al [9] Cells were frozen in $1 \mathrm{ml}$ ampoules contanng $1 \times 10^{6}-5 \times 10^{6}$ celts, $70 \%$ RPMI $164020 \%$ sereened pooled human AB plasma and $10 \%$ dimethylsulfoxide and stored at $-196^{\circ} \mathrm{C}$

\subsubsection{Antigen reactivatien and cloning of I lymphocytes}

Cloning of $\mathrm{T}$ lymphocytes was performed as described elsewhere $\left[\begin{array}{ll}10 & 11\end{array}\right]$ In brsef PBL of two leprosv pat!ents (BC and $\mathrm{R})$ were restimulated in vitro with $M$ leprae in IMDM supplemented with $10 \%$ IS during 5 days at $37^{\circ} \mathrm{C}$ in a fully humulified $5 \% \mathrm{CO}_{3}$-air mixture $\mathrm{T}$ cell blasts were obtaned either by Percoll density centrifugation or by extending the cultures for another 3-10 days in the presence of $10 \%$ inter leukin 2 (IL 2, Lymphocult-T, Brotest, Frankturt, FRG) The blasts were cloned under limiting dilution conditions ( $05 \mathrm{ccll} /$ well) on a irradiated teeder cell layer contanmg autologous EBV-BCL as antigen-presenting cells (APC), and optimal concentrations of $M$ leprae antigen All cultures were pelformed in IMDM supplemented with $10 \%$ iS in 96-well flatbottom microtiter plates (Microtest III 3072, Becton Dickınson. Sunnyvale, CA) Growng cultures were transferred to 24-well flat-bottom plates (Fdlcon 3047 Becton Dickinson) and restimulated with antigen and irradiated feeder cells every two weeks Three days after each antigen feeder icstimula tion $20 \%$ IL 2 was added Ihe cells were from $3-10$ days after the find restimulation

\section{$2.1 .3 \mathrm{CTL}$}

The following CTL were used in the cell-medattd lympholysis (CML) assays and in the proliterative assays (d) Allotmmune IILA-A2 1 subtype-specific CIL [12] (b) HLA-A1 and B8restricted minor histocompdtibility (munor-H) antigen ( $t$ minor HA-3)-specific CTL [13], and (c) HLA-A2 and/or HI A-B7-restrkted H-Y-specufic CTL [13\}

\subsection{Surface iodination, Immunopreciputaton and gel elcctrophoress}

All cells were surface lodinated undel carefully standardiced conditions essentidly as previously reported $[5,6]$ Briefly, vable cells were isolated from cultures or bufty cods on एicoli isopaque density gradients and washed twee in phosphatcbuffered salıne (PBS) with $10 \mathrm{mg} / \mathrm{ml}$ glucase The cells were rcsuspended at enther $5 \times 10^{7}$ or $10^{\circ}$ cells $/ \mathrm{ml}$ (cloned cells or $\mathrm{PBL}$ respectively) in PBS with I $0 \mathrm{mg} / \mathrm{ml}$ glucose and lac- toperoxidase $\left(10 \mu \mathrm{l} / \mathrm{ml}\right.$ of $1 \mathrm{mg} / \mathrm{ml}$ stock solution), $\mathrm{Na}^{125} \mathrm{I}$ $\left(100 \mu \mathrm{Cl}_{1}=37 \mathrm{MBq}\right.$ per $10^{8}$ cells $)$ and giucose oxidase $(10 \mu \mathrm{l} /$ $\mathrm{ml}$ of Sigma, Munich, FRG, G 6500 diluted $250 \times$ ) were added The labeled cells were washed twice in PBS and lysed with $05 \%$ purified Tiston X-100 in $50 \mathrm{~mm}$ Tris.HCl $150 \mathrm{mM}$ $\mathrm{NaCl}, 002 \% \mathrm{NaN}_{3}(\mathrm{pH} 75)$ at $5 \times 10^{7}$ cells/ml for 20 min on ice The lysate was cleared by centufugation $(400 \times \mathrm{g}, 10 \mathrm{~mm}$, $4^{\circ} \mathrm{C}$ ) and stored at $-80^{\circ} \mathrm{C}$ For immunoprecipitation $200 \mu \mathrm{l}$ aliquots of the cell lysates were precleared with $10 \mu \mathrm{g}$ purified mouse immunoglobulins (Nordic, Tiburg, The Netherlands) and precipitated with $25-43 \mu \mathrm{g}$ of the specific mAb $(30 \mathrm{~min}$ on ice) and $5 \mu \mathrm{l}$ rabbit anti-mouse immunoglobultn (Z 109 Dakopatts, Copenhagen, Denmark $30 \mathrm{~mm}$ on Ice)

Fixed Staph aureus cells (Calbiochem, La Jolld, CA) were used as immunosonbent Reduced or nonreduced sodium dodecyl sulfate (SDS) gels were run as previously reported $[5,6]$ The gels were stamed, dried under vacuum and exposed to Kodak XAR-5 films with Dupont Cronex L1-PLus intensifter screens at $-80^{\circ} \mathrm{C}$

\subsection{Antigens and antibodies}

$M$ leprae antigens were kindly provided by $\mathrm{Dr} M$ Abe ( $\mathrm{Nat}$ Inst Leprosy Research, Tokyo lapan) and by $\operatorname{Dr} R \quad C$ Good (Centre for Infectious Diseases, CDC. Atlatitd GA) Both preparations consisted of bacill solated from hum 1 n lepromas according to Dharmendia's procedue [14] with slight modifications The end concentrations of the fits preparation in the cultures are given in $\mu \mathrm{g} / \mathrm{ml}$, whereds those of the second preparation are expressed as find dilution in the cultures The $93 \mathrm{mAb}$ was originally prepared by 1 ansen et al [4] For the prosent experments, the $93 \mathrm{mAb}$ was bought from New Ingland Nuclear (Boston, MA), it was puritsed by proten $A$ affinity chromatography and found to be homogeneous by SDS gel electrophoresis Other monoclond antibodies used were directed aganst class I major histocom patibility antigen, $9455 \mathrm{SA} / \mathrm{BRL}$, W6/32, B9 121 (courtesy of Dr B Malissen), $\beta_{2}$-microglobulin. B11 G 6 (courtesy of Dt B Malissen), T3 antigen WT 32 (RIV Buthoten). T4, RIV6 P8, I K18, transferrin receptor, 68221 , $1 \mathrm{FA}$ i, 83141 , DR, B8 112 (courtesy Dr B Malissen), DQ, SPVL3 \& (courtesy Dr H Spits), 3Al-Jike detcrm!nant, 6451 and $\mathrm{C}_{3}, \mathrm{PdV} 102$

Godt antl-mouse fluorescen isothocyandte(FITC)-conju* gated immunoglobulin was purchased from Nordic Unless otherwise specified. all antibodies were used at previously determined optimal concentrations

\subsection{Cellular assays}

\subsubsection{Activation of cloned human $\mathrm{T}$ helper cells by $M$ leprae}

One $\times 10^{4}$ TLC and $5 \times 10^{4}$ urradiated (40 Gy) autologous or 11LA class II-matched peripheral hlood lymphocytes (PBL) as APC in IMDM with $10 \%$ HS wese cultured with $M$ leprac antigen in optumal concentrations in 96-well flat bottom microtiter plates (Gremur, Nurangen, $\Gamma R G$ ) Phytohemdgglutnun (PIIA, Wellcome Diagnostics, Beckenham, GB, $4 \mu \mathrm{g} / \mathrm{ml}$ ) and plan IMDM were used as controls $93 \mathrm{mAb}$ was taken up in RPMI 1640 with 20\% IIS and dialyzed agdinst RPMI 1640) Varrous amounts of the dielyed antibody were added to the 
cultures calculated to give final concentrations ranging from $0001-10 \mu \mathrm{g} / \mathrm{ml}$ antibody

The cultures were set up in duplicate or troplic ste and incu bated as described above for $72 \mathrm{~h}$ Eighteen hours beforc to mination $10 \mu \mathrm{Cl}=37 \mathrm{kBq}$ of [methyl ${ }^{3} \mathrm{H}$ ] thymedinc $\left(\left[{ }^{3} \mathrm{H}\right] \mathrm{dThd}\right.$ spec act $50 \mathrm{Cl} / \mathrm{mmol}$ Radiochemical Centrc Amersham, GB) in $005 \mathrm{ml}$ RPMI 1640 was added The $5 \mathrm{im}$ ples were harvested on glass fiber filters using a semt dutonld tic device $\left[{ }^{3} \mathrm{H}\right] \mathrm{d}$ Thd incorporation was assessed by liquid $\mathrm{sen}$ tullatton counting As a control parallel cultuses were sct up with the anti $3 A 1$ like antibody 6451 in comparable dilution directly from pure ascites

\section{4.2 Mixed lymphocyte culture (MLC)}

MLC werc set up by culturng 50000 responder and 50000 irradiated (2000 rds) stımulator cells in V well microtıter trays in $015 \mathrm{ml}$ of RPMI 1640 supplemented with $15 \%$ pooled human $\mathrm{AB}$ serum and $50 \mu \mathrm{g} / \mathrm{ml}$ gentamycin (Flow Lab Irvine Scotland) The cells were cultured for $120 \mathrm{~h}, 18 \mathrm{~h}$ before harvesting, $1 \mu \mathrm{Cr}$ of [ $\left.{ }^{3} \mathrm{H}\right] \mathrm{dThd}$ was added to each cul ture Antibodies were added at the stat of the MLC and lcft throughout the culture period

\section{4.3 Lymphocyte transformation $t$ tsts}

Lymphocyte ta ansformation tests were carried out as follows 50000 responder cells (PBL or fluorescence actrited ctll $40 \mathrm{I}$ ter (FACS) separdted cells) were cultured in flat bottom mi crotitertrays in $015 \mathrm{ml} /$ well of tissue culture modiun (RPMI 1640, gentamycin $50 \mu \mathrm{g} / \mathrm{ml} \quad 15 \% \mathrm{HS}$ ) containung either $5 \mu \mathrm{g} / \mathrm{ml}$ purified proten derivative of tuberculin (PPD Statens Serum Institute Copenhagen) $075 \mathrm{I} / / m$ l tet mus tox ord (TT, RIV Bilthoven The Netherlands) of $5 \mu \mathrm{g} / \mathrm{mll}$ PHA Cultuie, incubation time and $\left[{ }^{3} \mathrm{H}\right] \mathrm{dTh}$ incorporation were carried out as described in Sect 242 PBL activatud by PIIA to be labeled and ummunoprecipitated at dav 03057 werc treated as above but $20 \%$ interleukın 2 (IL 2) was added to the medium after diy 3

\section{Cell-mediated lympholysis (CML) assay}

The allommune and the MHC restricted CTL populations were generated according to the culture piocedules described earher [12 13] The effector calls were pre incubater, for $30 \mathrm{~min}$ with three different concentrations of the $9{ }^{7} \mathrm{mAb}$ before addition of the specific target cells The CML a sis has been described in detall [ 13 15] The percentages of lysis ucre determmed in relation to PHA stmulated blast celis in a $4 \mathrm{~h}$ ${ }^{51} \mathrm{Cr}$ assay Cytotoxicity ( $i e$ the amount of isotepe reledsed from ${ }^{51} \mathrm{Cr}$ labeled target cells) was determined and calculated according to the described method [13] Standard errors of the mean of tuplicate determinations were less than $5 \%$ Postive and negative assignments were made on the bask of a $10 \%$ speafic ${ }^{51} \mathrm{Cr}$ release value All experiments west reprated it least twice at different uffector to targct ratios

\subsection{Indurect immunofluorescence and HACS analysis}

Analysis of indirect surface immunofluorescence and cell sort ing were carried out with a E ACS IV (Becton Dichinson Sun nyvale $\mathrm{CA}$ ) as reported elsewhere [16]

\section{Results and discussion}

3.1 Inhibition of response to antigen of cloned $\Gamma_{h}$ cells

Class If restricted cloncd $T_{h}$ culls specitic for $M$ leprar inte gens were derived from leprosy patients as provously icported $[10$ 11] The activation of a number of these $T$ cell clones by $M$ leprae ds a function of the $93 \mathrm{mAt}$ in the concentr mon range of $0001-10 \mu \mathrm{g} / \mathrm{ml}$ was me surned by incorpor ation of $\left[{ }^{3} I I\right] d T h d$ into macromolecul ir nucluc alcids It w 1 found th it the $93 \mathrm{mAb}$ stiongly inhibitcd the intigen response on $4 \mathrm{~mm}$ of these clones ( $\mathrm{eg}$ clones $4 \mathrm{A4} \quad 2 \mathrm{~F} 92 \mathrm{~F} 10)$ whercas the mhi bition in other clones was werk ( $\&$ clone $6(7)$ o p k ktk th absent (clone 2G11 see $\Gamma \mathrm{g}$ 1) In these litter cabes mbibs ton was observed only it very high $93 \mathrm{mAb}$ conccint! $11 \mathrm{~km}$ In the strongly mbibited clones the inhibiters attect is is tirst observed at $\mathrm{ng} / \mathrm{ml} 93 \mathrm{mAb}$ and regularly muladsed with the antrbody concentration The pricticalls const mt nogitic

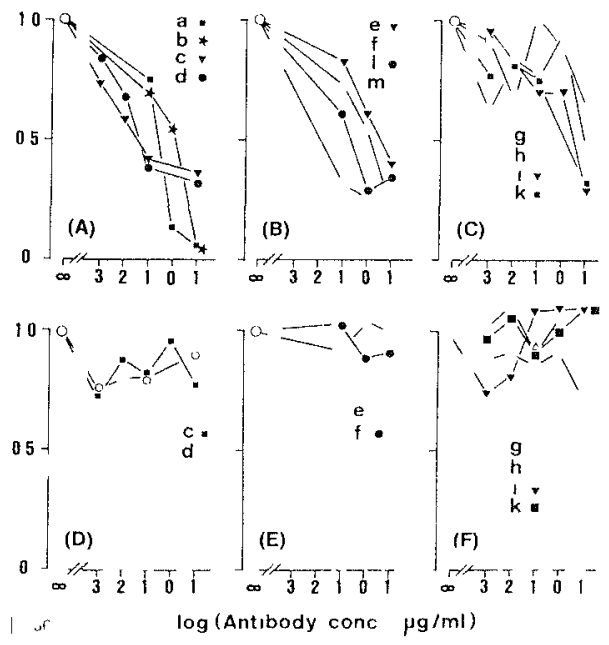

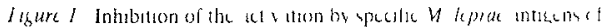
clonced human I cells by $93 \mathrm{mAb}$ in the concente thon $r$ thet of

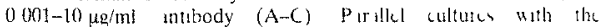

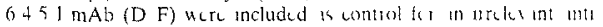

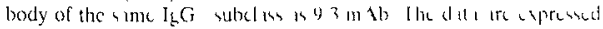
is rel stice minbation cocordme to

$\left(1-\frac{\mathrm{cpm}_{\mathrm{c}}-\mathrm{cpm}}{\mathrm{cpm}}\right)$

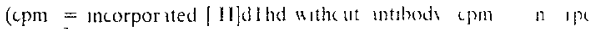

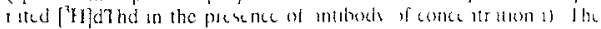

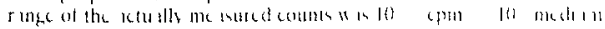

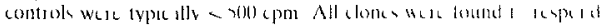

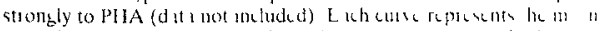
of triple ate cultues of on independene cxpeniment ut and isd errom

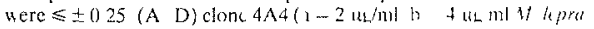

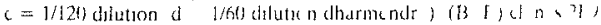

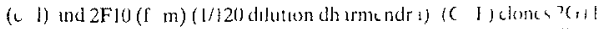

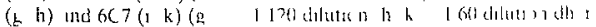

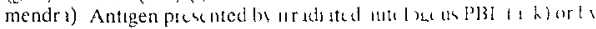
EBV BCL (l m) 
slope of the dose response curve in these clones contrasts sig nificantly with the practically antibody independent responses in parallel cultures with the $6451 \mathrm{mAb}$ which for the pur pose of the present investigation may be considered as an irrelevant control antibody of the same $\lg G$ subclass as the $93 \mathrm{mAb}$ The negative result of this latter control experiment allows to rule out that the effect of $93 \mathrm{mAb}$ is due to trivial phenomena such as antibody dependent cytotoxicity

All curves in Fig 1 represent independent experiments which have been carried out during a period of about one year Within that period the extent to which a given clonc responded to the inhbitory effect of the $93 \mathrm{mAb}$ in the $M$ leprae stimu lation assay was found to be reproducible the response to the $93 \mathrm{mAb}$ thus appears to be a specific and stable property of the individual clones at least within that period It 15 worth noting that all these clones in functional assiys behave as cldss II restricted $T_{h}$ cells [10 11] furthermore they all respond well to mitogenic stimulation by PHA (ditd not shown) The different responses in the assays presented in Fig 1 therefore are not due to differences in the guneral prolifer itive potential among the clones

\section{$3293 \mathrm{mAb}$ minbition of $M$ leprae activation is proportional to r90/44 expression of the different $T_{h}$ cell clones}

To discover the cause of the variability in the $93 \mathrm{mAb}$ depen dent inhubition of the activation by $M$ leprae among the differ ent cell clones the level of expression of TO0/44 and of a number of reference antigens was investigated I ysatcs of sur face lodina ed cells were sequentially immunoprecipitated with a panel of $\mathrm{mAb}$ the immunoprecipitates were then iden tified in SDS gels by autoradiography as undicated in Fig 2 the bands were cut from the gels and the incorporated radiodc tivity was counted ( $F_{1} g$ 3) To evaludte the dita in $F_{1 g} 3$ LFA I should be considered first

In a series of preliminary experiments it had becn found th it the level of expression of IFA 1 when compired to that of other surface antugens is the most constant imong the difterent cell clones This conclusion is confirmed by IIg 3 A mean of $18000( \pm 6300) \mathrm{cpm}$ are incorporntcd in the large subunit of

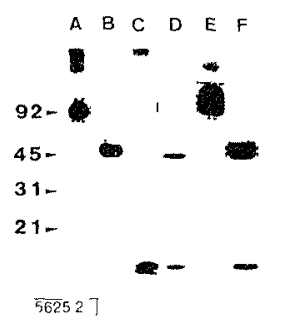

Figure 2 Immunoprcapitated T90/44 and HI A cliss I molcculcs (A) clone 4A4 To0/44 nonreduced (B) clone $4 \mathrm{~A} 4 \mathrm{r} 90 / 44$ after reduc ton of disulfide bonds (C) clone $2 G 11$ I90 44 nonreduced (D) clone 6C7 HLA class I (E) PBL T90/44 nonreduced (F) PBL I90/ 44 after reduction of disulfide bonds The precipitates in (A) (D) represent cell aliquots of $10^{7}$ cells The precipitates in (E) $(F)$ repre scnt $>10^{4}$ celis For the me tsurement of incorporated a adiol abel the bands were cut out as indic ated by broken lincs
LFA 1 per $5 \times 10^{7}$ cells of the different clones The amount of radiolabel in the small subunts are similarly constant so that the ratio of radiolabel in the two subunits is $467 \pm 054$

The remarkable constancy of LГA 1 expression is in contrast to the HLA class I molecules where large variations among the different clones are found It is noteworthy however that HLA heavy chan and $\beta_{2}$ microglobulin vary to the same degree the ratio of the radiolabel incorporated in the hedvy and light chans respectively is $259 \pm 049$ for the 6 cell clones These results support the conclusion that Fig 3 relı ably represents the relative level of expression of the surface antigens when the different cell clones are compared

It appears from these data that the inhubition by $93 \mathrm{mAb}$ of the $M$ leprae activation correlates well with the level of T90/44 expression in d given clone This is most clearly seen by com paring clones $2 \mathrm{~B} 2$ or $2 \mathrm{~F} 10$ with clone $2 \mathrm{G} 11$ Clones $2 \mathrm{~B} 2$ and 2F10 express high levels of T90/44 (5900/4300 cpm precipi tated) and are strongly inhibited at $\ll 1 \mu \mathrm{g} / \mathrm{ml} 93 \mathrm{mAb}$ clone 2 G11 expresses little T90/44 (1100 cpm precipliated) and is only weakly inhibited at the highest $93 \mathrm{mAb}$ concentration

As was to be expected from their $T$ helper phenotype all the clones tested express similar lcvels of 54 antigen [10 11] It was however unexpected that clone $2 \mathrm{G} 11$ and to a lesser extent clone $6 \mathrm{C} 7 \mathrm{in}$ addition to $\mathrm{T} 4$ express relatively high levels of $\Gamma 8$ antigen which does not appear to interfere with their helper function With regard to the simultaneous expres sion of T4 and T8 antigens in these clones it is of interest that in further blocknng studtes anti $\mathrm{T} 4 \mathrm{mAb}$ but not ant $\mathrm{T} 8 \mathrm{mAb}$ were found to inhibit the activation of clone $2 \mathrm{G} 11$ by $M$ leprac (data not shown) The present data do not show whether the finding that the two $\mathrm{T}^{+}$clones $2 \mathrm{G} 11$ and $6 \mathrm{C} 7$ also have 7 relatively low expression of T90/44 has a functiond signifi cance All the cell clones tested by the immunoprecipit ations were found to express smilar amounts of $D R \alpha \beta$ and $D Q \alpha \beta$

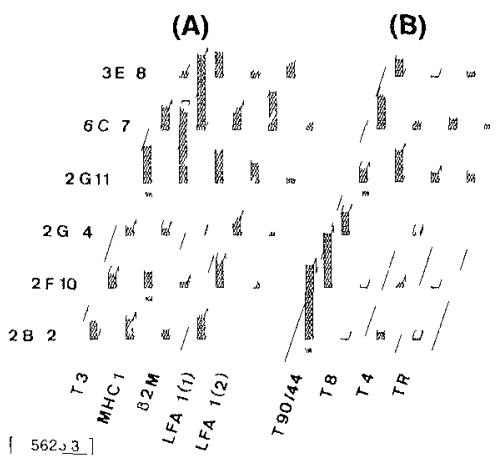

I gurc 3 Incorporated ridioaulivity (cpm $\left.{ }^{25} \mathrm{I}\right)$ in T90/44 and refer ence antigens immunoprcepitated from surface lodinated call clones 2B2 2F10 2G4 2G11 6C7 3E8 (A) 13 class I antigcns he tvy chath (MHC I) $\beta_{2}$ microglobulin ( $\left.\beta 2 \mathrm{M}\right)$ LFA 1/large subunit [LFA 1(1)] and I FA l/small subunt [LFA $1(2)]$ (B) T90/44 T8 T4 transfersm jeceptor (TR) The columns in (B) relative to those in part $(A)$ of the figure are scaled up by a factor of 93 The incorporited radioactivity per $5 \times 10$ cells is indicated in all fields below the columns in units of cpm 
(data not included in Fig 3) and of transferrm receptors (Fig 3) This finding corroborates the above conclusion from the functional assays that dil the clones have a comparable prolferative potentral becduse these surface molecules may be viewed ds markers for the cellular actıvation state

Furthermore since the clones $2 \mathrm{G1 \perp}$ (Iow T90/44) and $4 \mathrm{~A} 4$ (high T90/44) were derived from the same leprosy patient BC (DR3 4/DRw52 53/DQw3/DPw1 5) whereas the other clones were derived from patient $\mathrm{R}$ (DR2 3/DRw52/DOw1 2/DPw5) it can be concluded that the level of T90/44 expression does not correlate with that of class II antigens

It is noteworthy that the analysis of the cell surface immuno fluorescence in the FACS IV yielded results which were con sistent with those of the immunoprecipitations in Fig 3 Therefore, the amount of radioactivity incorporated into the vdrious cell surface antigens by the present iodination protocol also by this criterion may be considered a good tpproximation of their relative amounts when the different cell clones are compared $\mathrm{A}$ fu ther result of the FACS malysis was that the expression of r90/44 in a given cell population is homogene ous For example the low T90/44 expression in the $2 \mathrm{G} 11 \mathrm{ccll}$ clone ts duc to the equally low expression in all cells $r$ this than to the presence of positive and negative calls bec uuse only one single peak of positive fluorescence is recorded in the FACS IV immunofluosescence profile

\section{Effects of $93 \mathrm{mAb}$ on cytotoxic $\mathrm{T}$ cell lines}

Three class I restricted CTL ( $i$ c HLA A 1 ind B8 restricted ant1 minor $\mathrm{H}$ antigen specific C7L HLA A2 and B7 restricted $H$ Y specific CTL and HLA A2 1 specific allom mune CTL [12 13]) were used to investgate whether the $93 \mathrm{mAb}$ is capable of interfering with cytotoxic functions It had been cstablished by prior immunoprecipitations that these CTL express simildi amounts of T90/44 ds those $M$ leprae activated $\mathrm{T}_{h}$ clones with high T90/44 expression (sec ibove) whon measured on a per ecll bisks or relative to expression of the class I intigens (d at a not shown) The function il cltclts of the $93 \mathrm{mAb}$ and of several reference antibodies on the cellu lar cytotoxicity was investigated in a CML assay It was found that the $93 \mathrm{mAb}$ in contrast to the refurence antrboties which had various mbibitory effucts was not capable of intei fering with the cytotoxic function of any of thesc ( $\mathrm{CI}$ (Table 1)
In a further approach to define the regulatory mechanisms in which T90/44 plays a functional role the effects of the $93 \mathrm{mAb}$ on the proliferdtive rather than the cytotoxic actrittes of these CTL vere investigated The ILA A2 1 allommune and the HLA A2 restruted $H Y$ specific $C 71$ were stimulated in a 5 day MLR with their specific stimulator cells and co cultured with varous concentrations of $y 3 \mathrm{mAb}$ and antı T3 where ifter [ $\left.{ }^{3} \mathrm{H}\right] \mathrm{dTh}$ incosporation was me isured (Table 2) The proifferation of both CTL was found not to be significantly modulated by the $93 \mathrm{mAb}$ an contr ist to the pronounced inhibitory effect of the 113tt $\Gamma^{3} \mathrm{mAb}$ (T ible 2)

In further experiments the $93 \mathrm{mAb} w$ is testcd for its bility to inhibit natural killer activity or antibody dcpendcint collul ir cytotoxicity and was found not to inhibit in those us mis it a not shown)

\section{Lymphocyte transformation tests}

First indications that T90/44 his a functrond. aok in 7 cell activition were provided $b$ the linthng thit $y \quad m A b$ enhances mitogenic responses of PBL 10 cuboptim il 6 mecon trations of PHA or to allogencec cclis whereds no dincet mitogune effect of the intibody could be decend $[5]$ these results were confurmed and culconded by tin dircct mutogenic action of 93 mAb w 4 documcitcd in 2 more lecent report [8] To inestig ite this point in more det is the effects of $93 \mathrm{mAb}$ and of sever ll icfercnce intrbudtes were studicd in a serres of lymphocvte trinsform iton tests corruct out with PBL of 2 untelited donors (T $\mathrm{blc}$ 3) stions cnhanccments of the proliter litve responses to PPD and 1 i (20 30 fold) were found which support the pressouslv reported growth enhancement phenomena [, 7] vo effect of $93 \mathrm{mAb}$ on the cultute activated by PHA is detectud becarisc the PHA here is used in optimally activiting concentrition ([5] see Sect 24 3)

Thu above transformation tests werc carned out in RPMI 1640 mఒdium supplemented with 15r HIS [3 7] Howcver when the PBL wh1t cultured in RPMI 1640 mudium supplemented

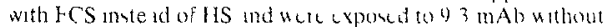
iny fut ther autivating factors a strong dicct mitoge nic kion of $93 \mathrm{mAb}$ becdme apparent wheh nc arlv cquilled that found with anti $\mathrm{T} 3 \mathrm{mAb}$ (Table 3 last column) This dited mitogenic action of $93 \mathrm{mAb}$ is in sherp conir sst with the ab sence of any actrvation di equivalent antibodv concentr tus in in medaa supplemented by HS [5 7]

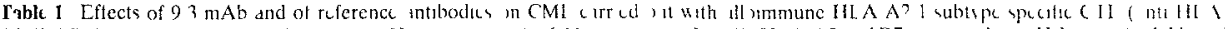

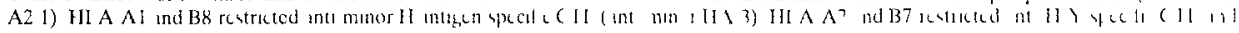
spcalic targct culls

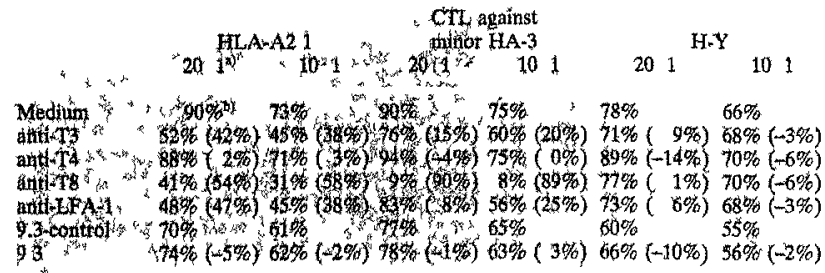

7) Effuctor t urget ccll ritio

b) Percent ige of target cell thom ind it inhibition of lysu (an parenthesce) Is the vartous entibodits ire wen is the medn of tripic ite celture $11 \mathrm{kI}$ VII $16+0 / 1 \gamma^{\prime \prime}$ Hs 


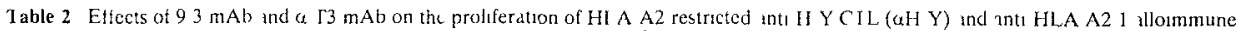
CTL $\left(\alpha A 2\right.$ I) in 5 day MLR with specific target cclls the incorpor ited $\left[{ }^{3} \mathrm{H}\right] \mathrm{d}$ Ilid is givert as the mean cpm of triplicate cultures

\begin{tabular}{|c|c|c|c|c|c|c|}
\hline CTL & $\mathrm{mAb}$ & & & ly concentration & & \\
\hline & & Medium & 0001 & 0010 & 0100 & 10 \\
\hline anti $\mathrm{H}-\mathrm{Y}$ & $\begin{array}{c}93 \\
\text { antl T3 }\end{array}$ & $\begin{array}{l}21010 \pm 3460 \\
23045 \pm 925\end{array}$ & $\begin{array}{l}24580 \pm 540 \\
24965 \pm 1315\end{array}$ & $\begin{array}{r}21170 \pm 640 \\
8900 \pm 250\end{array}$ & $\begin{array}{r}20720 \pm 1340 \\
3085 \pm 375\end{array}$ & $\begin{array}{r}26020 \pm 585 \\
2550 \pm 15\end{array}$ \\
\hline ants A2 1 & $\begin{array}{c}93 \\
\text { antz } \cdot T 3\end{array}$ & $\begin{array}{l}24560 \pm 280 \\
17675 \pm 285\end{array}$ & $\begin{array}{l}29510 \pm 477 \\
18405 \pm 605\end{array}$ & $\begin{array}{r}33060 \pm 5330 \\
9265 \pm 1550\end{array}$ & $\begin{array}{r}38590 \pm 2380 \\
4953 \pm 32\end{array}$ & $\begin{array}{r}37520 \pm 7135 \\
5140 \pm 10\end{array}$ \\
\hline
\end{tabular}

The antibody concentration dependence and the possible role of monocytic cells in the drect $T$ celi actrvation by $93 \mathrm{mAb}$ were investigated PBL of the two donors wert depleted of monocytes by sorting out cells stanned with PaV 102 (anti monocyte) $\mathrm{mAb}$ on the FACS IV The cells wore then cul tured in medium supplementud by $10 \%$ FCS to reveal the direct mitogenic dction of $93 \mathrm{mAb}$ A strong proliferative response to $93 \mathrm{mAb}$ agan was found at $56 \mu \mathrm{g} / \mathrm{ml}$ dntıbody and $25 \times 10^{\circ}$ cells $/ \mathrm{ml}$ with PBL the monocyte depleted $l y m$ phocytes did not respond to $93 \mathrm{mAb}$ but its mitogenic iction could be restored by re adding aradiated autologous PBI to the purified lymphocytes (Table 4 ) I he cell activation trig gered by $56 \mu \mathrm{g} / \mathrm{ml} 93 \mathrm{mAb}$ nearly equals that in the $\alpha \mathrm{T} 3$ inAb or PHA controls

This direct mitogenic action is only found at high antibody cell ratios it has practically vanished already at the fourfold higher dilution of $93 \mathrm{mAb}$ (Table 4 ) whurc is the crhancement of growth piomoting signals is detccted cven at $\mathrm{ng} / \mathrm{ml} 93 \mathrm{mAb}$ [5]

It may be concluded that the mitogem action of $93 \mathrm{mAb}$ depends on the prescnce of monocytcs and is quenched by HS A likely cause of the suppression of the mitogense action in medid supplemented by HS is their relatrvely high content in human immunoglobuln molecules it might thon be proposed that the binding of $93 \mathrm{mAb}$ to $\Gamma \mathrm{c}$ receptors of monocytes and ds a consequence the possible clustering of $790 / 44$ is function dlly important This hypothesis is further supported by the recently reported finding that $F(a b)_{2}$ but not $F$ itragmonts of $93 \mathrm{mAb}$ have functiona] effects on [ cells [17] However it cannot be excluded that the quenchung by IIS is at least in part due to the presence of material which reacts with $93 \mathrm{mAb}$ (eg shed T90/44) [5]

\section{$3.5 \Gamma 90 / 44$ expression is induced in activated $\Gamma$ cells}

Comparative immunoprecipitation studies had rovealed that both the class I restricted CTL and the class II restricted $M$ leprae activated $T_{h}$ cell clones express signuficantly larger amouts of T90/44 than resting PBL It was theiefore postulated that $\Gamma 90 / 44$ expiession is induced in activated $T$ cells To inves tigate this hypothesis PBL of two unrelated donors wure cul tured in the presence of optimally detivating concentrations of PIIA and (after day 3) of IL 2 Aliquots of cells werc surface lodinated at day () 35 and 7 of PIA activition T90/44 together with other representative surface antigens wore immunoprecipitated from cell lysates the respective bands weie cut from SDS gels and the incorporated iddioldbel w is counted It was found that the adioactivity per cell which is incorpotated into T $90 / 44$ increased regularly from day 0 to day 7 by factors of $6-10$ (Fig 4) Whereas similar results wcrc observed with DR $\alpha \beta$ and DQ $\alpha \beta$ and with the transferrm receptor less pronounced increases were found with the LFA 1 or class I antigens The expression of still other surface ant gens was not affected by the cell activation for example the radiolabel incorporated into the 43 antigen []6] remaincd practically constant throughout the whole activation period (Fig 4)

The surface rodination of cells and the immunopreripitations werc carried out under carefully standardiecd corditions they

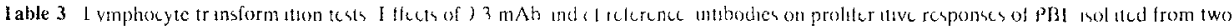
unrelited donors $A$ and B clicited by PliA PPD and II

PHA

$\begin{array}{llrrr}\text { Medium } & \text { A } & 59917 \pm 1198 & 5292 \pm 847 \\ & \text { B } 67135 \pm 24169 & 16170 \pm 1455 \\ \text { Anti-T3 } & \text { A } & 65810 \pm 1316 & 147900 \pm 7395 \\ & \text { B } 78490 \pm 3140 & 127100 \pm 5084 \\ \text { Ant T4 } & \text { A } & 55913 \pm 559 & 5988 \pm 1257 \\ & \text { B } 64803 \pm 1944 & 10067 \pm 1711 \\ \text { Anth-T8 } & \text { A } 56093 \pm 1122 & 4578 \pm 1099 \\ & \text { B } 67700 \pm 1354 & 11700 \pm 3510 \\ \text { Antı LFA-1 } & \text { A } & 21840 \pm 655 & 618 \pm 272 \\ & \text { B } 35003 \pm 2450 & 2668 \pm 1387 \\ 93^{\text {b) }} & \text { A } 61613 \pm 1232 & 107393 \pm 8591 \\ & \text { B } 70383 \pm 704 & 79780 \pm 15158\end{array}$

IJ

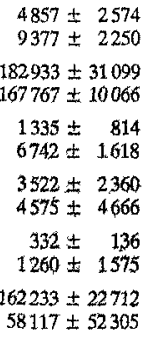

Medium/10\% FCS

$273 \pm 19$
$288 \pm 66$
$63593 \pm 636$
$52580 \pm 2629$
$298 \pm 36$
$343 \pm 58$
$138 \pm 26$
$220 \pm 31$
$257 \pm 41$
$243 \pm 83$
$41330 \pm 7026$
$20697 \pm 1656$

a) Cells of two donors $A$ und $B$ were cultured in RPMI 1640 medium supplumented by $15 \%$ HS (PIIA PPD TT) or by $10 \%$ FCS (Med um last column) Mean (pm and st und ird deviation (triplicate cul tures) of ancorpot ited [7y]d rhd b) $56 \mu \mathrm{g} / \mathrm{ml}$ 


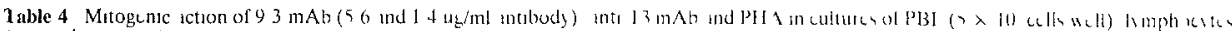

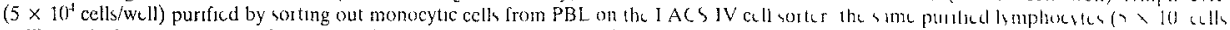

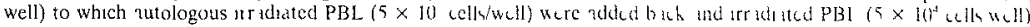

\begin{tabular}{|c|c|c|c|c|c|}
\hline & & $=\underset{*}{P B L}$ & Lymphocytes & $\begin{array}{c}\text { Lymphocytes } \\
\text { PBL }\end{array}$ & $\mathrm{PBL}^{*}$ \\
\hline Medtund & $\mathbf{A}_{\mathbf{B}}^{\mathbf{t}}$ & 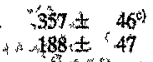 & $\begin{array}{l}117 \pm 34 \\
102 \pm 20\end{array}$ & $\begin{array}{rr}262 \pm 52 \\
260 \pm 159\end{array}$ & $\begin{array}{l}232 \pm 16 \\
632 \pm 929\end{array}$ \\
\hline $\begin{array}{l}93^{(j)} \\
\left.\tau_{*}^{*}\right)_{b}^{*}\end{array}$ & $\mathrm{~A}$ & 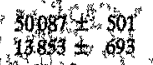 & $\begin{array}{l}223 \pm 120 \\
122 \pm 41\end{array}$ & $\begin{array}{r}.22587 \pm 2710 \\
21 \pm 50 \pm 1480\end{array}$ & $\begin{array}{l}8095 \pm 648 \\
2092 \pm 209\end{array}$ \\
\hline 3 tet? & $\mathbb{A}$ & $\begin{array}{l}1825 \pm 547 \\
402 \pm 129\end{array}$ & 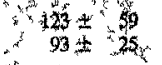 & $\begin{array}{l}2815 \pm 366 \\
1098 \pm 121\end{array}$ & $\begin{aligned} 210 \pm & 57 \\
88 \pm & 20\end{aligned}$ \\
\hline Antr-13 & A & $\begin{array}{l}67350 \pm 20020 " \\
44183 \pm 2209\end{array}$ & $\begin{array}{l}355 \pm 291^{2}+ \\
212 \pm 85\end{array}$ & $\begin{array}{l}41183 \pm 2471 \\
36390 \pm 1456\end{array}$ & $\begin{array}{r}15447 \pm 927 \\
6489 \pm 519\end{array}$ \\
\hline HA & $\begin{array}{l}\mathrm{A} \\
\mathrm{B}\end{array}$ & $\begin{array}{l}61933 \pm 1858 \\
58253 \pm 1165\end{array}$ & $\begin{array}{l}10950 \pm 547 \\
19827 \pm 1586\end{array}$ & $\begin{array}{l}43433 \pm 1303 \\
52743 \pm 2109\end{array}$ & $\begin{array}{l}20250 \pm 1417 \\
13740 \pm 550\end{array}$ \\
\hline
\end{tabular}

d) $\mathrm{PBL}^{*}$ - Irr idilited PBI

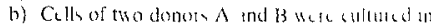

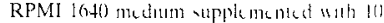
FCS

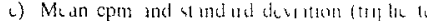

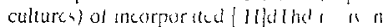

d) $26 \mathrm{Hg} / \mathrm{ml}$

c) $14 \mathrm{ug} / \mathrm{ml}$

refer to the same activity reference date of ${ }^{175} \mathrm{I}$ Fuithermole microscopic mspection confunted that pidctically dill the cells in the culture vere uniformly transformed The iadiodctivity incorporated into a given surface antigen thus is a goud approximation for the relative number of its copies per all when the cells of a given donor are compdied throughout the activation period It may then be concluded that the Ty0/44 expression increases at least in proportion with the cell surface arca in the blast transformation in view of the steeper mcrease of T90/44 when comparca to that of class lor LFA 1 it c mnot even be excluded that the cell surt ice densty of $\Gamma 90 / 4+4$ in the PHA blasts is higher than in resting cells

(A)

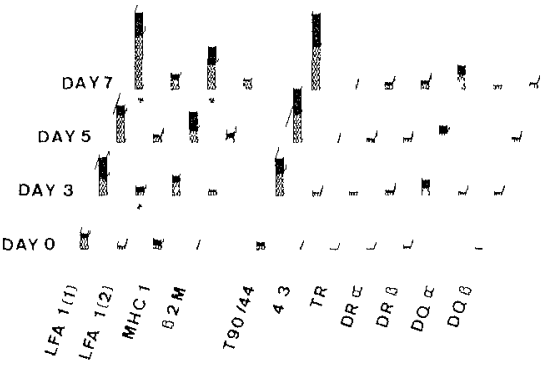

$[156 \overline{25} 4$

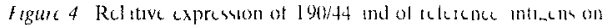

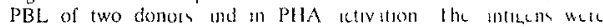

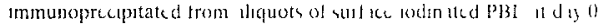

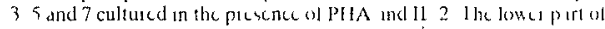

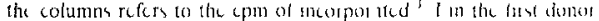
the tot d height of the columns refus to cym encorpor thed' I In the second donor (A) LIA $1 / 1$ irge $\mathrm{KD}$ i subunt [I FA $\mid(1)]$ ind im ill subunit [I ГA I(2)] class 1 antigen heavy chaln (MHC I) $\beta$ micro globulin (B) T90/44 43 intigcn (4 3) 1ronslerrin scceptot (IR) Cl ise II untigens DRa $\beta$ and DOa $\beta$ The columos on $p$ art $(B)$ achere te those in pat (A) of the figure welc we led up by a fietor of 3 the incosporated radiodetivity pes $) \times 10^{7}$ celts of the second bonos tre given an all ficlds below the colsmats un units ol cpm

\section{Concluding remar ks}

The number of the different l cell sut ice intugem lmoush

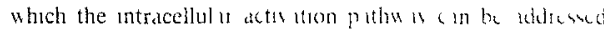
and which therelore can ktu te 1 colls mto poulder anon w small At piesent the T/T3 comples ind the CHI ntigen are known to belong to this cl ass of cull siat ice molecules $\mid 1$ i| The present results together with the provious finding on the functional effects of $93 \mathrm{mAb}$ [ $74 \mathrm{k}$ at hith doubt th it

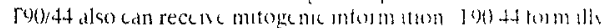

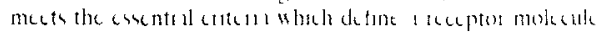

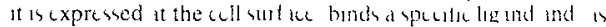
a consequence changes in coll tunction are mualuled $A$ icceptor tuncion of T90/44 theretore cinnot be cxcluded and to search for a physologe ligand in futhus studics might be justilied

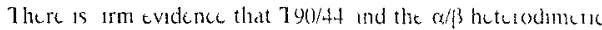
Tiale d strice genc products The suhunts of 790416 monot be icsolved anto separate bunds by a vinety of clcotrophoictic mothods whereas $\Gamma$ i consistc ntily is resolved unto a ind $\beta$ sub unts of different molecul a mass [1 $2256 \mid$ Furthormone 11 wa found th it $T 90 / 44$ and $\mid 3$ cannot be comodulated $\mid 7$ > 14) $790 / 44$ therctor 1 is independent of the kecpose stiuctur

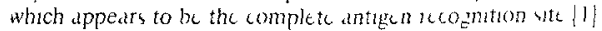
It may then be concluded th it the ictudatom through $[1 \%$ ) 44 is independent of antigen If the tume point 13 the 7 cell ictis tion process at wheh $790 / 44$ might tunction is a d lut ted the

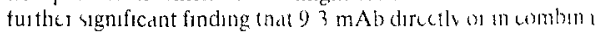
tion with phorbol esters induces II 2 and IL ' ILcuptos wpes

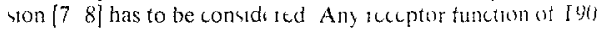
44 then would have to be placed in the perod befort II II ?

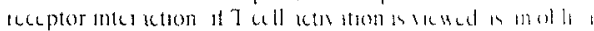

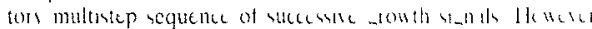
the presently ardalable $d$ at 1 do not fllow the a malusing tha triggciong of T90/44 is in oblig story stcp an sach a sequence The actixation through $190 / 44$ ather meht kpesent in an a gen andependent bypass of the TI T 3 complex 11 dek ot c.ll actiration pathways based on the latter issumption nould pro dict that a plimary activating sign il sccosed by the I I $36 \mathrm{~m}$ plex may become modulated by the mput of secomal in sah

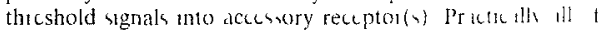
the functiond cfects of $93 \mathrm{~m}$ ab upotud if the wh m

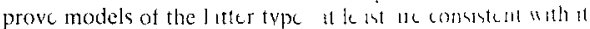


Any model of T90/44 function has to take into account the important finding that the $9.3 \mathrm{mAb}$ can either block or promote proliferation. The former is found in the inhibition of the specific response to $M$. leprae in the cloned $\mathrm{T}_{\mathrm{h}}$ cells; the latter is clearly documented in the mitogenic effect on resting lymphocytes in the presence of monocytic cells, FCS and high antibody concentrations or in the enhanced responses to PPD, TT and PHA (Table $3 ;[5,7,8]$ ). This apparent dichotomy of functional effects is consistent with various models. It may be envisaged that all growth-regulating signals either at the cell surface or intracellularly ultimately converge on a common biochemical pathway; if, furthermore, regulated feedback loops play a role along this pathway, it becomes obvious that depending on the status of the system the same receptor molecule may elicit positive or negative responses. The high level of expression of T90/44 in activated as compared to resting cells is likely to be one of the key factors which determine whether a positive or a negative signal is generated at T90/44.

The authors thank Dr. R. de Vries for stmulating discussions. The excellent technical assistance of Ms. Antta Hofer and Ms. Dienne Elferink is an essential part of this work. The generous gifts of monoclonal antbodies by Dr. B. Malissen (Marseille) and Dr. H. Sptts (Amsterdam) are gratefully acknowledged.

Received June 20, 1986.

\section{References}

1 Hood, L., Kronenberg, M. and Hunkapiller, T., Cell 1985. 40: 225.
2 Meuer, S. C., Fitzgerald, K. A., Hussey, R. E., Hodgdon, I. C., Schlossman, S. F. and Reinherz, E. L., J. Exp. Med. 1983. 157: 705 .

3 Meuer, S. C., Hussey, R. E., Fabbi, M., Fox, D., Acuto, O., Fitzgerald, K. A., Hodgdon, J. C., Protentis, J. P., Schlossman, S. F. and Reinherz, E. L., Cell 1984, 36: 897.

4 Hansen, J. A., Martin, P. J. and Nowinski, R. C., Immunogenetics 1980. 10: 247.

5 Gmünder, H. and Lesslauer, W., Eur. J. Btochem. 1984. 142: 153.

6 Lesslauer, W. and Gmunder, H., Mol. Immunol. 1986. 23: 271.

7 Hara, T., Fu, S. M. and Hansen, J. A., J. Exp. Med. 1985. 161: 1513.

8 Moretta, A., Pantaleo, G., Lopez-Botet, M. and Moretta, L., J. Exp. Med. 1985. 162: 823.

9 Steinitz, M. S., Koskimies, S., Klein, G. and Makela, O., Curr. Top. Microbiol. Immunol. 1978. 81: 156.

10 Ottenhoff, T. H. M., Klatser, P. R., Ivanyi, J., Elferink, D. G., De Wit, M. Y. L. and De Vries, R. R. P., Nature 1986. 319: 66.

11 Haanen, J. B. A. G., Ottenhoff, T. H. M., Voordouw, A., Elferink, D. G., Klatser, P. R., Spits, H. and De Vries, R. R. P., Scand. J. Immunol. 1986. 23: 101.

12 Poel, J. J., Van der Pool, J., Goulmy, E., Giphart, M. J. and Van Rood, J. J., Human Immunol., in press.

13 Goulmy, E., Progr. Allergy 1985. 36: 44

14 Dharmendra, D., Lepr. India 1942. 14: 122.

15 Bruning, J. W., Van der Poel, J. J. and Kardol, M. J., in Ferrone, S. and Solheim, B. G. (Eds.), HLA typing, Vol. II CRC Press, Boca Raton 1982. 2: 99.

16 Koning, F., Bakker, A., Dubelaar, M., Lesslauer, W., Mullink, R., Schuit, R., Ligthart, G., Naipal, A. and Bruning, J. W., Human Immunol., in press.

17 Ledbetter, J. A., Martin, P. J., Spooner, C. E., Wofsy, D., Tsu, T. T., Beatty, P. G. and Gladstone, P., J. Immunol. 1985. 135: 2331.

18 Ottenhoff, T. M. H., Koning, F., Gmunder, H., Giphart, M. and Lesslauer, W., Expertentia 1985. 41: 787. 